\title{
Conflict Resolution: Military Operation or Peace Deal
}

\author{
Musab Yousufi \\ M. Phil scholar at Department of International Relations \\ Preston University Kohat, Islamabad Campus \\ E-mail: musab_yousufi@live.com
}

Musa Khan

M. Phil scholar at Department of Media and Communication Studies International Islamic University Islamabad E-mail: musakhan_85@yahoo.com

\section{Doi:10.5901/jesr.2013.v3n3p309}

\begin{abstract}
Conflict in the form of military operation, terrorism or civil war has a strong effect on the behavior of people and plays destructive role in the activities of government and public lives in the regions. Conflict of one state with another occurs many times for scarce resources but sometimes secondary sources also involved like border or terrorism issues etc. In this research paper main elements of conflict and military operation have been investigated and discussed. There were some effective elements that promoted conflict in the regions. First is the bad administration and lack of good governance that weakens local loyalty for the government. Second was of government's negligence and wrong policies towards particular issues and areas. Third were economic dislocation, fourth illiteracy, strict culture norms and negative use of media instruments. The media instruments have been used by interest groups to mould the public opinion in their favor. These all elements have open rooms for insurgent groups to have footing and to exploit the situation according to their agenda. In this research paper solutions for conflicts also have been examined by references of different theories and practical examples.
\end{abstract}

Keywords: Military Operation, Terrorism, Civil War, Conflict, Insurgent Groups, Media Instrument

\section{Introduction}

In the world million of innocent people suffered and got physical, economic, educational and social disabilities and now still are getting such disabilities because of conflicts. Conflicts usually occur in the form of military conflict and non-state actor conflict between the states. Also some time military operations and non state actors within the state. We also saw the World War I, World War II also Cold War and Post Cold War era that's also the era of conflict between states. During those wars and conflicts innocent common people suffered more than military and militants. The infrastructure of those targeted areas was damaged and social life of people was totally destroyed.

For the solution of conflicts and disputes military use is not the only way to resolve the problems. According to history from infinite incident it is clear that table talk and peace deal is also a better solution than military operation. In many areas or states settlement and peace agreement regulated and solved problems.

We have seen the rise of peace agreement after World War II slowly matured. We also see in modern world many of civil wars have been terminated because of institutionalism like United Nations or European Union etc. Even Europe which was the field of battles and wars now makes an effort to solve any such problem or conflict through table talk and negotiation. It means that the international psyche is also aware and wants the solution of conflicts by negotiation and table talk and also wants to regulate peace agreements. United Nations guidelines and recommendation to Security Council was also to solve problem through peace agreement, negotiation and table talk.

\section{Literature Review}

\subsection{Liberal Idealist Approach towards Peace:}

Liberal idealists believed that "the pen is mightier than the sword" the three liberal groups give three main ideas to maintain peace. First is to make international institutionalism like United Nations that institution eliminates the wars 
conflicts and anarchical system of the world. Second group says that arbitration and mediation is also a way to settle the disputes and eliminate the arm conflicts. They mean negotiation, table talk and to sign the agreement and pact within two parties. The third group followed the command of Bible "biblical injunction" that is "those who live by the sword die by the sword" (Charles and Kegley 2007-2008, p. 27).

The liberalism believes on equality, dignity, liberty of individual and protects people from unnecessary state regulation. They also followed the moral values and virtues and also emphasize ethical principles over pursuit of power and institutions. The liberal believe that international relation can run orderly and international wars, conflicts and anarchic system of world can be reduced and eliminated by international organization. They say that there has to be some institutions like UN, SAARC, Arab League, OIC, and EU etc that can control and monitor the relations among states. SAARC, OIC etc these all are regional organizations and liberalist say that we have need of mechanism to enforce the law to reduce tendency of war by collection of regional organizations. They also argue that arms race also promotes conflicts, wars and disputes. Liberalist also support arm control agreement and institutions that control arm race with the result conflicts and wars can be reduced in the world. But when we talk about institutionalism there must be care about equality and equal power sharing in an institute among states or member of the institute. There will be no priority to any member of institute like we take the example of UN. In UN we see a special power of veto to some five countries. If all 138 or more state members of the UN oppose or agree with a bill and if out the five veto members even one member wants to veto that bill he has the rights to veto it therefore this is not equality and not equal power sharing among the members of the institute.

The liberalism also follow the democracy, interdependency and as we discus institutionalism. They also talk about equality, according to their view all these things maintain peace and eliminate conflicts and war in the world.

Another important thing for maintaining peace is also human rights, when the basic needs of people are fulfilled no one goes towards war and conflicts (Featherston, 2000).

\subsection{Immanuel Kant and Peace:}

Immanuel Kant was a Germen philosopher gave three answers to eliminate conflicts and regulate peace. The first is, all states shall develop the institutions and organizations to facilitate cooperation like today's United Nations or European Union etc. Kant gives the idea of institutions because that institutes monitor the act of states and enforce the collective policies on them. Kant's second idea is that peace depends on the internal character of government that character is head of state or Kant uses the word of monarch. Kant also argues that there should be a department of state to make sure the 'check and balance' on government departments. Department also cares about the policies of government and control the head of state from that kind of policies which create wars in the surrounding world. Kant's third answer for maintaining peace is trade, he says that trade increase wealth, corporations and global well-being. Trade is also improving through institutionalism like (WTO) World Trade Organization etc. That entire network reduces disputes and conflicts because no government wants to harm its state economy (Goldstein and Pevehouse 2007, p. 84).

The trade organization like International Political Economy (IPE), General Agreement on Tariff and Trade (GATT) create benefits for states. Because they restrict the states form that kind of policies which create conflicts, wars and destabilize and injure the state economy.

As Kant limits the head of state, now in the $21^{\text {st }}$ century during crisis, country security decisions are made by small advisory boards of the head of the state. Small group of advisors, and not by large scale of bureaucracies means, that they limit the bureaucratic organization. In most of the decisions only the head of state is involved and no other person is involved in decisions like elected government, oppositions and bureaucrats etc. That kind of decisions create wars, conflicts and disputes with in a state and as well as out state border (Kegley, 2007-2008, p. 77). Kant says that the people have check and balance on the prince or head of state because the monarch wants to cover more land. The people are not more selfish than the monarch therefore monarch goes towards conflict and war to gain more power and cover more land, resources and area (Baylis et al, 2008, p. 112). In most countries the various decisions are taken by army or non political parties or institutions are involved in the decisions usually because of the power and control of dictators or army in the state. We can take the example of Arab spring, in many countries like Egypt, Libya, Morroco, also the situation of Syria and other countries in the world where dictatorship or military is stable, most of the civil wars occur in those states and countries because of improper check and balance on the head of state and miss use of power and authority on the people by those dictators. While in the result of that injustice and inequality the wars between states or war within state which we called civil war arose. We can also take the example of Pakistan, during military era from 1999 to 2009. Military took many decisions without consulting the bureaucrats, present member of national and provincial 
assembly, and even the prominent and political persons of country were not consulted. We see the results of that decision in Pakistan in the form of civil war, a war with in the state, insurgency and non state actor.

\section{Sources of Conflict}

According to Ron Fisher conflict is the nature of all humans and it is a social behavior of people to fall in conflicts. It occurs because of social, ethnic and psychological differences among the people.

Conflict is defined as an incompatibility of goals or values between two or more parties in a relationship, combined with attempts to control each other and antagonistic feelings toward each other (Fisher 2000, p. 1).

They define three sources of conflict;

\subsection{Economic conflict}

Economic conflict is about gaining the limited resources. Every person and party desire to gain more and more as we discussed earlier that head of state or monarch wants to capture more land and resources and there has to be a department of state to maintain check and balance on them (Fisher 2000, p. 2).

\subsection{Value conflict}

Worth conflict it means conflict for ideology like e.g. Cold War. Each party wants to emphasize its ideology and political and economic system. Also because of this the conflict occurs (Fisher 2000, p. 2).

\subsection{Power conflict}

Power conflict takes place when everyone or each group and party wants to maintain maximum power. It is not possible that each party has power in a system there must be a weaker party, as a result the stronger party emerges. Power conflict can occur between states, nation, individual, and groups etc. Power conflict also occurs within state like we see in many states that non state actors challenge the writ of government in states (Fisher 2000, p. 2).

\subsection{Function of institutions in conflict emergence}

Institutions play vital role in conflict emergence and conflict resolution if those institutions are governmental, semi governmental or public institutions in the form of political or social institution.

Swiss Programme for Research on Global Issues for Development conducted a research on the topic of Causes of Solutions to Social Conflicts in Contexts of Weak Public Institutions or State Fragility. They also mentioned the sources and causes of conflict. They mention that political and social institutes contribute in conflict emergence. Conflicts occur because of corruption, dishonesty, inequality, injustice and social and political instability. State weakness like lack of social development institutions, financial instability, poverty and also leakage between societies (discrimination) also erupt conflict. Natural resources as we discuss also promote conflict in society. Each party wishes to gain more of the scarce resources because of that also we see conflict in the society. As Russia has interests in Central Asia and especially in Caucasian region, where the war has already begun between Chechnya and Russia and also more other small states and Russia, it is only for natural resources. Russia wants full control on those regions to use the resources of those regions according to its wishes therefore we can still see the dictatorship in most of countries from that region. Mostly those dictators were made in 1990s and 1991 or in the time of separation and division of USSR by the wishes of Russian government. But situation of Baluchistan issue in Pakistan is not only for limited resources while they claim dishonesty, inequality, injustice etc from their political leaders and social, financial and political instability from political leaders as well as from country government.

Oliver Ramsbotham mentioned in his book contemporary conflict resolution, that conflict is human nature and it arose by inequality, economic dislocation, instable political system and the mismatched goals between parties or groups. He also mentioned those things which we discussed earlier like scarce resources, apartheid, injustice etc. They mention and focus on the mutually incompatible goals, those aims and objectives on which the parties are not together according to them this is also the main source of emergence of conflict among families, groups, parties and states (Ramsbotham 2011, p. 7). The situation of separation, east and west Pakistan. That conflict was within the state conflict between two 
political parties at that time. Both parties aims and objectives were incompatible and mismatched as a result we can see the separation. The situation of Sudan division, Sudan is also divided in to two states. But now the situation in Afghanistan is different that's why the so called Taliban and present government are in conflict because of incompatible goals and both have different aims and objectives.

Marie Doucey also mentioned in her work that instable political system, inequality etc are the cause of conflict but she mentioned that only the scarce resources are not the root cause of conflict but when secondary sources are combined then conflicts emerge (Doucey 2011, p. 3-5). Conflict between America and Afghanistan is not only on the base of resources but it is also about the terrorism and the so called war on terror. It is against Taliban because of 9/11 issue. Marie Doucey also explained the Burton work and says that when the human need is not full filled like food, water, shelter and financial support then conflicts emerge.

They further explain worldwide and general need of people on which compromise is not possible like security, independence, identity, recognition, respect, family and community. Then the people feel injustice and inequality with the result conflicts can emerge (Doucey 2011, p.3-5). The independence movements in India like Naxal or Naxalite movement and also Sikh or Khalistan independence movement also independence of Kashmir etc. Those movements not only claim the resources but first they claim injustice and unequal distribution of wealth, lack of independence in political and economic system, security, freedom etc.

\subsection{Role of Media in conflict emergence}

Media is an important tool which plays and played a vital role in the construction or destruction of any society or nation. During any kind of conflict this tool may be use to propagandize some sensitive issues which may leave strong effects on the behavior and mind settings of audience towards extremism, According to magic bullet theory the information of media inject in the mind of audience like a fire bullet and the audience quickly respond in the reaction (Neuman, 2011). According to uses and gratifications theory the users of media use the media for their satisfaction rather than media effect on these. According to this theory the media will passive while the listener will active (Katz et al, 1974).

But from the history it is cleared that in several wars the media has been used as a tool of war like in world war two the Germany (Nazi) use the radio as a propaganda tool in the war to build the pressure on the enemies and to get the sympathies of their nation and allies (Teering, 2003).

In the same manner during recent era the FM radios used by the militants in Pakistan to miss use the innocent, illiterate and poor people against the state and military. They tried and succeeded to some extent in their purposes.

\section{Resolution of conflict}

Many scholars of international relations, politics and social sciences give the theories and ideas of how to resolve conflicts. But some scholars like Burton, Fisher, Keashly's and Ripeness did much work on conflict solution and conflict management.

\subsection{Burton's Problem-Solving Approach}

Burton differentiates the dispute and conflict. According to Burton dispute and conflict are two different things, dispute is negotiable and solves easily also compromise is possible and negotiable. While conflict is deeply rooted in human behavior and solving of conflict is so systematic and demands struggle but solving is impossible and not negotiable.

Conflict resolution theory develops the different methodologies, procedures and different strategies for problem and conflict settlement. The meaning and aim of conflict resolution strategies is to resolve the problem and the root cause of conflict and maintain peace by negotiation, arbitration and dealing. The core method is developed by conflict resolution scholars called problem-solving process. features:

According to Burton, practices can be considered part of a systematic problem solving process if they have four

- The only objective and aim is not to find the solution for conflict resolution while the mean is to establish the relationships through by which the problem can be handled as they arise.

- They also require the understanding and identifying of sensory information about conflict and its context on the part of participants. 
- They also argue that to understand the context logically that is, why the problem or conflict arose in the first place?

- Finally, they tackle the source of conflict frustrated needs (Fetherston 2000, p. 5).

They further explain his theory that when a problem arose at that time solving of problem is possible and establishing relationships through which problems can be handled and resolve as they arise. While the government has to see critically and systematically the problems and they have to try to control such problems and conflicts. As we see almost every government does not see the issue at time of creation and later the issue converts into conflict and then to war. As the Pakistan situation is also like that, the government gives no attention towards terrorism in the beginning that's why conflicts arise in the region. The government has also no strong attention towards solving the problem, peace agreement and to involve political parties and to know the causes of conflict. But when they did peace agreement then they also leave some gaps in peace agreement.

\subsection{Technique and strategies of conflict resolution}

The common and simple approach to conflict resolution is to involve the both parties by direct negotiation between them. Both parties mean states or government to the armed opponent and challenger who challenge the writ of government within state or out state border. Second is also a common approach that they have to use cease-fire approach and to stop exercising power. The next is little difficult process that they call the all international and domestic mediators or influential and political people for negotiation and signed written agreement publicly (Bell, Vol 100-373, p373).

Fisher further explains the methods of conflict resolution and gives three techniques for conflict settlement. The win-lose approach is simple approach to resolve conflict that one group or party win and other lose. We see around us in daily routine by simple example in sports grounds one team wins and the other loses. Sri Lankan army defeats the Liberation Tigers of Tamil Eelam in 2009. Next they explain lose-lose approach that the both parties lose something like separation of Sudan and also division of east and west Pakistan, both lose the specific land and resources. Then win-win strategy in it no party can lose and this is best approach for conflict resolution. In this approach the both parties are not against each other while both are against the problem means both parties and groups versus problem. This technique is difficult to combine both groups on single issue but it is sustainable (Fisher 2000, p. 4).

\subsection{Role of parties' attitude in conflict resolution}

Fisher and Keashly's combine work on conflict solving strategy;

"Once a conflict is initiated, the perceptions, attitudes and interaction of the parties become crucial elements of determining its further course. Typically, there is an escalating spiral of increasing intensity in which the relationship between the parties moves toward destructive competition and finally to a 'malignant social process' from which the parties are unable or unwilling to extricate themselves" (Fetherston 2000, p. 6).

Fisher and Keashly's argument also argue that the conflict starts from the attitude of parties for one another. Typically there is rising coil or flame which increases conflict between two parties and moves toward destructive competition from which the parties are unable to move from conflicting themselves. While they have to sit and do dialogue, table talk or peace agreement for conflict resolution in the presence of mediators and show some flexibility from both sides. For conflict resolution it requires good mediators from elites, top leaders, middle leaders, low level leaders and also some support from society, while they also need good offices for negotiation and table talk. As Cordula Reimann mentions in his work on conflict transformation Track I, Track II and Track III actors or diplomacy and their strategies (Reimann 2004, p. 6). We have seen the terrorism issue in Pakistan is happening by the attitude of both groups. Also they cannot provide good mediators and good offices for resolution. Also Taliban issue with Afghanistan government now they are going to stabilize the good mediators and good offices for negotiation with Taliban in Qatar.

Ripenes's theory is encouraging the parties towards negotiation to remove conflict among them, if that resolution or conflict settlement by negotiation or mediation succeeds. Dean G. Pruitt explains the ideas of I. William Zart-man that how to shift within state wars and international wars towards settlement. There are two main steps towards negotiation and conflict resolution.

- "Conflict settlement occurs when both parties mutually realize the conflict resolution by costly deadlock (expensive settlement in the form of guaranty or labiality). Then the settlement will be sustainable in present and future also. 
- Resolution of conflict mutually occurs when both sides foresee that "a negotiated solution is possible" then parties come to satisfactory position" (Pruitt 2005, p. 1).

We see the Darfur Sudan's situation is to resolve by satisfaction of both parties while in this conflict the good mediators were involved from rest of the world and provide him good and satisfactory offices for settlement. Conflict resolution occurs by mutually hurting stalemate. If both sides realize that we cannot want conflict settlement than it is impossible to solve the problem. From both sides a negotiated solution and flexibility is necessary. As the situation of South Africa's Nelson Mandela encouraged the white Africans to finish the conflict because of apartheid policies and he also motivated the black Africans to end the war and conflict. Gorbachev ended the cold war to negotiate with the west, because of no output from war but more humans suffered and also wastage of wealth and power.

In Pakistan civil war also first both parties were not agreeing to solve conflict through peace agreement. But when they sat for peace agreement to solve conflict then for some time the government backed out and after some time militants backed from the agreement. Pakistan government also did many peace deals with the militant groups in Wana Waziristan, FATA like Shakai agreement with Taliban leader Nek Muhammad, Sararogha Peace Deal with Mehsud dominated areas of South Waziristan, and PATA areas in Malakand Division they also did many peace deals with nonstate actors like SWAT agreement the peace deal in Swat was struck on April 20, 2008 between the Awami National Party-led provincial government and followers of the Tehrik-e-Nifaz Shariat Muhammadi (TNSM) led by Sufi Muhammad (Tajik, 2011). In India like independence Kashmir movement and Nagorno-Karabakh War between Armenia and Azerbaijan etc. But those peace deals did not reach to a fruitful end due to lack of interest from either part of the groups.

\section{Conclusion}

Military operation has positive as well as negative impacts on the people and areas but mostly it has negative impacts on society, either it occur within the state or among the states. While in this research study the researcher examined that non state actor (insurgent groups, terrorists or extremists) destroyed, good social value of the society. Because of improper check and imbalance rules and regulation of government in such areas, the illegal activities took place which changed the behavior of the public toward extremism like terrorism or Taliban issues in Pakistan, Naxel and Khalistan issue in India or Tamil in Siri Lanka. But those issues are within state. While between state conflicts also took place many times through above things, like improper check and imbalance of government rules, regulation and week diplomacy, or as Kant mention Institutionalism, trade, check and balance on head of state. Conflicts between states like Pakistan and India wars or United State in Iraq or Afghanistan etc. also happened due to mentioned problems.

The proper check and balance of mature government brings awareness regarding positive activities, education, peace and social development in the society while improper check, imbalance and lack of maturity in government brings negative change in country policies, diplomacy and suffer the behavior of people towards awareness and positive thinking.

Mostly Conflicts take place for resources but some time the secondary source also involved like United State of America or NATO in Afghanistan because of Terrorism, but France in Mali not for scarce resources. Internal problems of any state make the way clear for non state actors or terrorists, as well as it also open room for foreign extremists or terrorists to have footing.

Whatever socially, financially and politically a state cannot be developed where the literacy is low, and culture norms are strict. Misinterpretation of religion also play role in the formation of extremism. In the case study of terrorism in Pakistan, it has been examined that the insurgent groups tried to misinterpret the religion and did try to use the innocent, sentimental and illiterate people against the state and military. They also hit the jobless society easily with the use of money and facilities.

Dictatorship and week governmental systems also promote conflicts within state like Arab Spring and also create disputes between states as liberalist mention for it democratic peace. The taken decision by people not by prince, would be drastically reduced the clashes and conflicts. Institutionalism and regionalism like SAARC etc also play role to minimize conflicts but some time because of their less function and non active role, they cannot control the clashes between states.

During research it is examined that the different scholars has different ideas and perception about conflict resolution. But most of them preferred to resolve conflicts through peace deal and mediation. They argued that military operation may silent the conflict or clash between two parties for time being but it leave effects for long term. During this research it has been examined that many times at different places the military has been used for conflict resolution but they could not successes to bring peace. 
In this research paper it has been investigated that the main reasons of conflicts in specific areas were Bad administration, lack of good governance, negative use of media instruments, Economic dislocation, illiteracy, strict culture norms, poverty and unemployment, negligence of government policies towards specific issues and areas, and misinterpretation of religion among the illiterate, innocent and sentimental people of the area.

\section{References}

Baylis John and others, Globalization of World Politics An Introduction to International Relations. London: Oxford, 2008.

Babbitt Eileen and Hampson Fen Osler. "Conflict Resolution as a Field of inquiry: Practice Informing Theory." International Studies Review, no 13 (2011): 46-57

Bell Christine. "Peace Agreement : Their Nature and Legal Status". The American Journal of International Law. Vol. 100 (2006): $373-$ 412.

Burton John Wear. System, State, Diplomacy and Rules. New York: Cambridge University Press, 1968.

Charles W and Kegly Jr. World Politics Trend and transformation. United State: Thomson Wadsworth, 2008.

Coleman, Peter T and others. Reconstructing Ripeness I: A Study of Constructive Engagement in Protracted Social Conflicts. Conflict Resolution Quarterly, Vol. 26, no. 1, Fall 2008.

Doucey Marie. "Understanding the Root Cause of Conflicts: Why it matters for International Crisis Management". International Affairs Review. Vol. XX, no. 2, Fall 2011.

Featherston Betts A. From Confict Resolution to Transformative Peacebuilding: Reflections from Croatia. Bradford: Centre for Conflict Resolution Departmwnt of Peace Studies Bradford University, 2000.

Fisher Ron Ph.D. "Sources of conflict and Method of Conflict Resolution". New York Springer-Verlag. (2000).

Fisher Roger and Ury Fisher. Getting to Yes: Negotiating Agreement Without Giving Yes. New York: Random House Business Books, 1991.

Goldstein Joshua S. and Pevehouse Jon C. International Relations. United State New Jersey: Pearson, 2009.

Hauss Charles. International Conflict Resolution. New York: The Continuum International Pulication, 2010.

Haq, Dr Noor ul and Imtiaz and Imtiaz asir. Swat Peace Accord. Islamabad: Islamabad Policy Research Institute, 2009.

Herbert Kelman C. "Conflict Resolution and Reconciliation: A Social-Psychological Perspective on Ending Violent Conflict Between Identity Groups". Landscapes of Violence, Vol. 1, no. 1 (2010).

Neuman Russell W. and Guggenheim Lauren. "The Evolution of Media Effects Theory: Fifty Years of Cumulative Research". Comunication Theory ISSN 1050-3293.Vol. 21, (2011) 169-196.

Katz Elihu and others. "Uses and Gratifications Research". Jstor. Vol. 37, no. 4, (Winter, 1973-1974): 509-523.

Pruitt Dean G. Whither Ripeness Theory?. Paper, Virginia: Institute for Conflict Analysis and Resolution, George Mason University, 2005.

Reimann Cordula. "Assessing the State-of-the-Art in Conflict Transformation". Bergh of Research Center for Constructive Conflict Management. (2005).

Swiss Programme for Research on Global Issues for Development. "Causes of andSolutions to Social Conflicts in Contexts of Weak Public Institutions or State Fragility". June 6, 2012.

Tajik, Sohail Habib. Analysis of Peace Agreements with Militants and Lessons for theFuture. Paper, Islamabad: Pakistan Institute for Peace Studies, 2011.

Teering Torsten. German Media During the Second World War. Munich: GRIN Publishing, 2003.

Tiernay Michael. Battle Outcomes and Peace Agreements. New York: New York University, Sep 15, 2011. 
